\title{
Application of DEA Method to Evaluate Financial Health of Selected Transport Companies
}

\author{
Martin Telecký ${ }^{1, *}$ \\ ${ }^{1}$ University of South Bohemia in České Budějovice, Faculty of Economics, Department of \\ Accounting and Finance, 37005 České Budějovice, Czech Republic
}

\begin{abstract}
The paper strives to apply the selected bankruptcy and creditworthy models on the transport companies operating under the conditions common in the Czech Republic. The paper aims to assess credibility of individual classification models which will be consequently verified by the DEA method. The task is to support or refute the hypothesis within the identification of the most effective unit, i.e. a transport company. The result is to determine the ranking of transport companies based on the results of the application of bankruptcy and creditworthy models and the application of the DEA method. Consequently, the hypothesis will be supported or refuted.
\end{abstract}

\section{Introduction}

The aim of the financial management is to obtain a complete overview of the financial situation of the company and the financial aspects. It is necessary to know more information to determine the basic objectives of the company in the future. To do so, it is necessary to identify the customers, suppliers, competitors, a quality of provided services, etc. Assessment of the company's financial health is part of efficient decision-making. It is necessary to find out the status of financial doubts and which measures can be applied. The efficient management of the company requires the optimum level of the assets, debts, forms of financing the operating activity using the company's own or external capital, the amounts of costs and revenue and the amounts of income and expenditure.

If the company is able to earn sufficient money and to comply with its obligation, it will not become insolvent and there will be no risk of bankruptcy. It means that the financially healthy company can report sufficient return and find the optimal sources of financial risk coverage. The financial risk is associated with the use of various forms of capital and the risk of financial insolvency.

The financial health of the company cannot be directly calculated but it can be determined upon the diagnostic methods using the financial analysis which is utilized by the general public and various economic entities with the aim to obtain information on the management and economic situation of the given company. Every economic entity focuses

* Corresponding author: telecm00@jcu.cz 
on a different type of information. The company management is interested in the information from all points of view, namely, whether its company

- is liquid,

- is solvent,

- generates a profit,

- is taking on a risk in case of an investment and how big this risk is,

- background and assumptions for further development.

The financial analysis utilizes the diagnostic methods which evaluate the company's management from the viewpoint of the past, the presence and the expected future. The aim is to reveal the weak points which could entail serious problems in the future and to start to build-up the financial success and company advantages on the strong points [1-2].

\section{Methods}

Classification models distinguish between two main groups of models, namely:

- bankruptcy models,

- creditworthy models.

Bankruptcy models, also known as prediction models, were compiled and investigated using the detail analysis of individual financial indicators which were applied to the various types of samples of examined companies (accounting entities). The main goal of bankruptcy models is to warn against a possible bankruptcy of the company "in time". The main factors are such selected indicators which imply a threat to the financial health of the company.

Bankruptcy models differ from creditworthy ones. They were and are created upon the real data. Creditworthy models, on the other hand, take into consideration the theoretical knowledge and on some models they answer the question whether the company creates a certain value for the owner and the investors (financial performance of the company). The goal is to classify the companies by the degree of their financial health, from the very strong to very weak undertakings. Most creditworthy models are evaluated upon the amount of points of the relevant ratio indicators. The achieved score should illustrate a certain degree of financial health [3-4].

\subsection{Bankruptcy Model Index IN 95}

This bankruptcy model was created by the Neumaiers spouses who received the Nobel Prize. They compiled the so-called credibility index IN. The application was carried out on the basis of the Czech accounting reports under the conditions of the Czech economy. They, thus, considered both the Czech accounting reports and they relied on the economic situation of the country.

The index IN 95 for the "transport" industry has the following form:

\section{$0.22 *$ assets / external resources}

$0.11 *$ earnings before interest and taxes (EBIT) / interest payable

8.33 * earnings before interest and taxes (EBIT) / interest payable

$0.52 *$ revenues / assets

$0.10 *$ current assets / (short-term liabilities + short-term bank loans))

$-16.8 *$ overdue liabilities / revenues 
The IN 95 index is a specific bankruptcy model designed for the Czech conditions. It means that it does not have the determined market value of the company in any single indicator. The model is designed for those companies which do not trade at the exchange. It is generally well known that there is a high level of insolvency in the Czech Republic. Mr and Mrs Neumaier considered this factor in the "overdue liabilities / revenues" indicator. It represents a certain inability of companies to pay off their debts in time (the index value is reduced) [5-6].

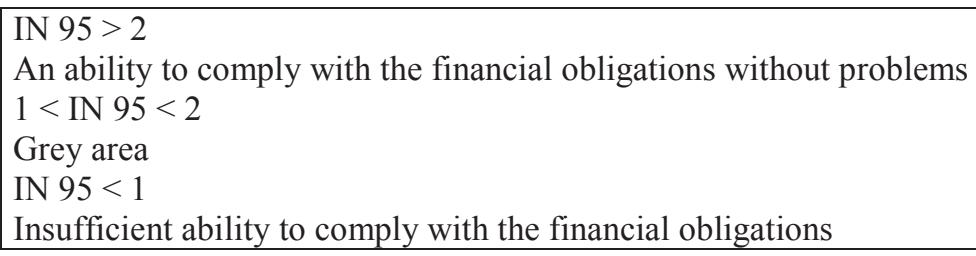

\subsection{Creditworthy Model IN 99}

The IN 99 index ranks among the creditworthy models that are specifically designed from the perspective of an owner. The discrimination analysis was used both on the IN 95 index and the IN 99 index. Weights of individual indicators differ from the IN 95 index. The reason is enforcement of achieving a positive value of the economic profit.

$$
\begin{gathered}
-0.017 * \text { assets / external capital } \\
4.573 * \text { earnings before interest and taxes }(\text { EBIT) / total assets } \\
0.481 * \text { sales / total assets } \\
0.015 * \text { current assets / short-term liabilities }
\end{gathered}
$$

The following information determines the final qualification of the company [5-8]:

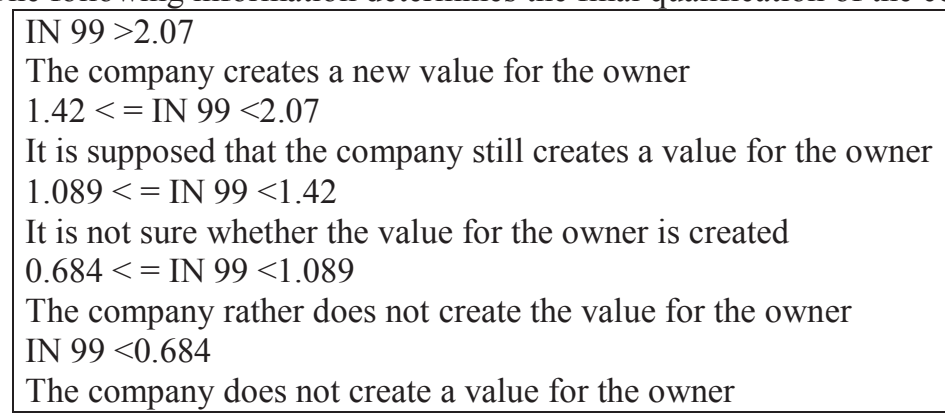

\subsection{Index IN 01}

This model was created upon the discrimination analysis. The IN 01 index is a specific model which takes into account the previous two models, i.e. IN 95 and IN 99. It is characterized as a bankruptcy and creditworthy model. It consists of five main indicators. This model does not contain the market value of the capital. It means that the model is especially designed for the companies not trading at the stock exchange. 


\section{$0.13 *$ assets / external capital}

$0.04 *$ earnings before interest and taxes (EBIT) / interest payable

$3.92 *$ earnings before interest and taxes (EBIT) / total assets

$0.21 *$ sales / total assets

$0.09 *$ current assets / short-term liabilities

The following information determines the final qualification of the company [5-8]:
IN $01>1.77$
The company creates a value.
$0.75<=$ IN $01<1.77$
The company does not create a value, yet it is considered creditworthy.
IN $01<0.75$
The company goes into bankruptcy.

\subsection{Index IN 05}

The IN 01 was helpful in creating the recent model IN 05. The goal of this model is not only to determine whether the company is near the bankruptcy, but to determine also a value for the owners. The prerequisite of this model is that it should estimate the bankruptcy of the company with probability higher than $72 \%$ [7-9].

$$
\begin{gathered}
0.13 * \text { assets / external capital } \\
0.04 * \text { earnings before interest and taxes }(\text { EBIT) / interest payable } \\
3.97 * \text { earnings before interest and taxes }(\text { EBIT) / total assets } \\
0.21 * \text { sales / total assets } \\
0.09 * \text { current assets / short-term liabilities }
\end{gathered}
$$

\footnotetext{
IN $05>1.6$

A company creates a value.

$0.9<$ IN $05<1.6$

A grey area of neutral results

IN $05<0.9$

A company destroys a value
}

We must not forget the fact that the indicator representing the interest coverage has very distorting effects in this model. These effects can result in the wrong rating of the company's financial health. Based on the authors' recommendation, it is apt to choose the maximum value 9 . The reason is that the interest payable tends to be close to 0 and the interest coverage indicator can achieve extreme values also provided that the weight is only on the level of 0.04 .

\subsection{DEA Method}

Thanks to its characteristics and functions, the DEA (Data Envelopment Analysis) method can analyse the economic, accounting and logistic issues in common practice. The result of the method is the information on the efficiency of individual activities (products) in the selected group in absolute terms and as a percentage. Unlike other methods, the DEA method is considered a new non-parametric method which evaluates the efficiency, performance or productivity of homogeneous production units. The main advantage is that the method allows us to evaluate efficiency of individual units (transport companies) 
individually within the chosen set of units. It shows which units are efficient and which are not efficient in performing their activity.

The DMU (Decision Making Unit) refers to an organizational unit which uses for its activity a certain number of inputs and outputs and represents the resulting values. The rule of selecting the lower number of inputs and the higher number of outputs applies. The unit's efficiency is calculated upon the following formula:

\section{Efficiency $=$ output/input}

This formula represents the simplest applicable case.

The CCR model maximizes the rate of effectiveness of the evaluated unit as a quotient of weighted outputs and weighted inputs on the condition that the rates of effectiveness of other units are less than or equal to one. The input-oriented CCR model focuses on such an amount of inputs which are consequently evaluated by this model. The model recommends such changes so that the ineffective unit becomes the effective one. At the same time, the model foresees the constant revenue of scale; i.e. the change in the amount of inputs will be directly proportional to the change in the output amount. For each unit this model will set individual weights of inputs and outputs to maximize the technical efficiency coefficient. Certain conditions, however, must be met, namely:

- Weights cannot be negative

- When using this set of weights for all entities, no coefficient of the technical efficiency must be greater than one.

The input-oriented BCC model is the modification of the previous model CCR. This model already takes into consideration the variable revenue of scale, i.e. increasing, decreasing or constant revenue. It foresees the variable, in certain parts linear revenue of scale and can evaluate the efficiency of entities for the generally non-constant output of scale [10-12].

A basic sample of transport companies which provide the traffic services using the public line transport in the selected regions of the Czech Republic was chosen. The bankruptcy and creditworthy models created by the Neumaiers for the companies doing business in the Czech Republic were applied on the data for the year of 2016.

The input data for the DEA method application was as follows:

Table 1. Input data for the DEA method analysis in the Czech crowns. Source: author

\begin{tabular}{|c|c|c|c|c|c|c|}
\cline { 2 - 7 } \multicolumn{1}{c|}{} & Assets & $\begin{array}{c}\text { External } \\
\text { capital }\end{array}$ & $\begin{array}{c}\text { Short-term } \\
\text { liabilities }\end{array}$ & $\begin{array}{c}\text { Interest } \\
\text { payable }\end{array}$ & Sales & EBIT \\
\hline CSAD A & 293891 & 114496 & 62849 & 980 & 334065 & 9435 \\
\hline CSAD B & 363539 & 146533 & 44216 & 378 & 226158 & 13222 \\
\hline CSAD C & 51529 & 49070 & 44138 & 0 & 927 & 379 \\
\hline CSAD D & 317752 & 269646 & 146167 & 2990 & 257011 & 8984 \\
\hline CSAD E & 192638 & 88319 & 34212 & 984 & 350643 & 15182 \\
\hline CSAD F & 414345 & 198180 & 117971 & 2185 & 475161 & 31452 \\
\hline CSAD G & 69812 & 64972 & 29427 & 1047 & 115781 & 1726 \\
\hline CSAD H & 376913 & 62445 & 36889 & 257 & 591624 & 72088 \\
\hline
\end{tabular}

Due to the sensitivity of economic data processing, the transport companies are marked with the letters. The author knows all economic and financial structures of individual transport companies. 


\section{Results}

Table 2. Indices IN 95, IN 99, IN 01 and IN 05 based on the calculation using EBIT. Source: author

\begin{tabular}{|c|c|c|c|c|c|c|c|c|c|c|c|c|}
\hline & & EBIT & $\begin{array}{c}\text { Overall } \\
\text { ranking } \\
\text { as per } \\
\text { EBIT }\end{array}$ & & EBIT & $\begin{array}{c}\text { Overall } \\
\text { ranking } \\
\text { as per } \\
\text { EBIT }\end{array}$ & & EBIT & $\begin{array}{c}\text { Overall } \\
\text { ranking } \\
\text { as per } \\
\text { EBIT }\end{array}$ & & EBIT & $\begin{array}{c}\text { Overall } \\
\text { ranking } \\
\text { as per } \\
\text { EBIT }\end{array}$ \\
\hline CSAD A & \multirow{8}{*}{$\begin{array}{l}z \\
8 \\
\text { un }\end{array}$} & 2.58 & 5. & \multirow{8}{*}{$\begin{array}{l}z \\
0 \\
0\end{array}$} & 0.69 & 5. & \multirow{8}{*}{$\begin{array}{l}z \\
e\end{array}$} & 1.1 & 5. & \multirow{8}{*}{$\begin{array}{l}z \\
\text { un }\end{array}$} & 1.09 & 4. \\
\hline \begin{tabular}{|l} 
CSAD B \\
\end{tabular} & & 5.28 & 2. & & 0.5 & 7. & & 2.23 & 2. & & 1.2 & 3. \\
\hline CSAD C & & 0.31 & 8. & & 0.04 & 8. & & 0.27 & 8. & & 0.27 & 7. \\
\hline CSAD D & & 1.44 & 7. & & 0.51 & 6. & & 0.57 & 7. & & 0.57 & 6. \\
\hline \begin{tabular}{|l} 
CSAD E \\
\end{tabular} & & 4.54 & 3. & & 1.26 & 2. & & 1.76 & 3. & & 1.51 & 2. \\
\hline \begin{tabular}{|l|} 
CSAD F \\
\end{tabular} & & 3.71 & 4. & & 0.89 & 4. & & 1.41 & 4. & & 1.2 & 3. \\
\hline CSAD G & & 1.88 & 6. & & 0.9 & 3. & & 0.67 & 6. & & 0.67 & 5. \\
\hline CSAD H & & 35.49 & 1. & & 1.67 & 1. & & 13.35 & 1. & & 2.5 & 1. \\
\hline
\end{tabular}

Table 3. Results found upon the DEA method analysis when the BCC model is applied. Source: author

\begin{tabular}{|c|c|c|}
\hline $\begin{array}{c}\text { Unit } \\
\text { name }\end{array}$ & Score & Efficient \\
\hline CSAD A & $66.10 \%$ & False \\
\hline CSAD H & $100.00 \%$ & True \\
\hline CSAD C & $100.00 \%$ & True \\
\hline CSAD B & $39.10 \%$ & False \\
\hline CSAD G & $91.10 \%$ & False \\
\hline CSAD D & $44.40 \%$ & False \\
\hline CSAD E & $100.00 \%$ & True \\
\hline CSAD F & $65.90 \%$ & False \\
\hline
\end{tabular}

The Table 2, which analyses the financial health of transport companies, lists the final values of individual bankruptcy and creditworthy models, including the final ranking from the best transport company to the worst one. The transport company CSAD H is a winner. It means that it has the best results of all transport companies under study. CSAD C, on the other hand, demonstrates the worst financial health in all classification models [13, 14].

The situation is, however, different after the DEA method is applied. The Table 3 shows which transport companies are rated as efficient and non-efficient. CSAD H can be considered an efficient unit. This statement is identical also as to the results of bankruptcy and creditworthy models which set the financial health as the best. The transport companies CSAD E and CSAD C are considered to be an efficient unit. According to the Table 2, CSAD E came second and third. CSAD C is almost last on the list. This implies that the bankruptcy and creditworthy models are not absolutely credible and fail to have a $100 \%$ explanatory power. Also other factors which affect the financial health of the company matter. An example is also the structure of the classification model itself which can more efficiently rate the financial health of the company [15]. The success of the models IN 95, IN 99, IN 01 and IN 05 is estimated with credibility of $57 \%, 81 \%, 52 \%$ and $62 \%$, respectively.

\section{Conclusions}

In the past, the models evaluating the financial health of the company, basically, consisted of the indicators which characterized the properties and actions of the company in the financial sphere. As the time goes by, the technology develops and the business processes 
improve, the new models are updated (innovated) or compiled to better evaluate the financial health of companies. They consider the factors which were not reflected in the past or were not so important to be addressed by the users. They were not substantial in the past. At present, it is necessary to create such classification models which would evaluate the financial health of the company in the specific fields of business at the given territory and not to apply the versatile bankruptcy or creditworthy models only.

The paper is drawn-up within GAJU 075/2017/S.

This paper is supported by the research project "From horse-drawn railway to intermodal transport" within Visegrad Fund.

\section{References}

[1] J. Fibírová, L. Šoljaková, Value Tools of Company Management and Performance Measurement, 1st issue (Prague: ASPI, a.s., Czech Republic, 2005)

[2] E. Kislingerová, J. Hnilica, Financial Analysis: Step by Step, 1st issue, 137 p. (Prague: C. H. Beck, Czech Republic, 2005)

[3] R. Grünwald, J. Holečková, Financial Analysis and Planning of the Company (2002)

[4] E. Kislingerová et al, Managerial Finance, 3rd issue, 811 p. (Prague: C. H. Beck, Czech Republic, 2010)

[5] R. Grünwald, J. Holečková, Financial Analysis and Planning of the Company, 318 p., (Prague: Ekopress, Czech Republic, 2009)

[6] I. Neumaierová, I. Neumaier, Company Performance and Market Value, 1st issue, 216 p. (Prague: Grada Publishing, Czech Republic, 2002)

[7] Finanalysis, Used Bankruptcy and Creditworthy Models, Available online: http://www.finanalysis.cz/pouzite-bankrotni-modely.html (2014)

[8] M. Vochozka, Methods of Comprehensive Evaluation of the Undertaking, 248 p. (Prague: Grada Publishing, Czech Republic, 2011)

[9] M. Zikmund, IN05 - Financial Analysis: Bankruptcy Index from the Czech Republic Which Works When Applied to the Czech Companies, Available online: http://www.businessvize.cz/financni-analyza/in05-bankrotni-index-z-ceska-kteryfunguje-na-ceske-firmy (2011)

[10] P. Fiala, Production System Modelling and Analysis, 1st issue, 260 p. (Prague: Professional Publishing, Czech Republic, 2002)

[11] J. Jablonský, M. Dlouhý, Efficiency Evaluation Models of Production Units, 1st issue, 184 p. (Prague: Professional Publishing, Czech Republic, 2004)

[12] R. Hindls et al., Statistics for the Economists, 7th issue, 420 p. (Prague: Professional Publishing, Czech Republic, 2006)

[13] M. Poliak, Š. Semanová, P. Varian, Logi - Scientific Journal on Transport and Logistics 5, 1, 51-60 (2014)

[14] R. Kampf, O. Stopka, I. Kubasakova, V. Zitricky, WMCAUS 2016 - World Multidisciplinary Civil Engineering-Architecture-Urban Planning Symposium, 15381544 (Procedia Engineering 161, Prague, Czech Republic, 2016), DOI: 10.1016/j.proeng.2016.08.623

[15] H. Bínová, E. Březina, Logi - Scientific Journal on Transport and Logistics 6, 1, 13$25(2015)$ 